\title{
Organické uloženiny fluviální výplně údolního dna řeky Bečvy u Oseku nad Bečvou a jejich vztah k vývoji sedimentace
}

\author{
Organic matter of the fluvial valley bottom infilling near Osek nad Bečvou and its \\ relation to sedimentary development
}

\author{
Jan Vít ${ }^{1} \llbracket$, Eva Břízová2 ${ }^{2}$ Tomáš Kolář ${ }^{3}$, Michal Rybníček $^{3}$ \\ 'Česká geologická služba, Brno, Leitnerova 22, 60200 Brno \\ 2Česká geologická služba, Klárov 3, 11821 Praha 1 \\ ${ }^{3}$ Mendelova univerzita v Brně, Zemědělská 1, 61300 Brno
}

Key words:

Bečva River, Holocene, river sediments, palynology, dendrochronology, radiocarbon datting

$凸$ jan.vit@geology.cz

Editor:

Milan Geršl

\section{Doporučená citace článku:}

Vít, J., Břízová, E., Kolářr, T., Rybníček, M. (2019). Organické uloženiny fluviální výplně údolního dna reky Bečvy u Oseku nad Bečvou a jejich vztah $k$ vývoji sedimentace. - Geologické výzkumy na Moravě a ve Slezsku, 26, 1-2, 66-72.

\begin{abstract}
Organic matter, like pollen, plant detritus or subfossil woods can be found in sequences of fluvial sediments. Detail study of these remains help to assess age of accumulation processes, especially during the Holocene erosion/accumulation cycle. Two localities with exposed infill of the Bečva River valley were found near Osek nad Bečvou. The first outcrop is a gravel pit $1 \mathrm{~km}$ south of Osek nad Bečvou village. The second one is a river-cliff on the left bank of the Bečva River, $1 \mathrm{~km}$ westward of Oldrichov village, formed mostly during the extreme flood in 1997. Fluvial sediments, 4-5 $m$ thick, of the the so called "lower flood-plain level" were exposed on both localities. At the base of the Oldrichov river-cliff was encountered a horizon of boggy soil with subfossil trunk at the base. In the gravel pit near Osek nad Bečvou was exposed layer of clay/silt with plant detritus. Up to $2 \mathrm{~m}$ thick middle/coarse grained gravel, situated beneath underground water level, underlie the organic-rich sediments in both localities. Badenian clay represents the bedrock of the river valley. Organic-rich layers are overlaid by middle/coarse grained gravel sediments passing gradually to sandy silt of the flood plain. Pollen analyses were made from the organic-rich layers and dendrological analysis, dendrochronology and radiometric dating from subfossil trunk.

Organic-rich layer from Osek (sample LS001) was assigned to the early Holocene based on pollen analysis and represents the oldest age found. The Oldrichov samples come from oxbow sediment. The sample LV030V was poor in pollen grains and inconclusive. The sample LV030Z indicates Holocene climate optimum (Atlantic). This supposed age is compatible with radiometric dating of the subfossil trunk from the base of the layer. Radiocarbon dating using wiggle matching method gave age of 7 070-6 775 BC.

Based on these data, repeated erosion/accumulation events during Late Pleistocene and Holocene are evident in Bečva River valley fill. Late Pleistocene accumulation was replaced with erosion during Late Pleistocene-Holocene transition. Erosion on the break of the Pleistocene and Holocene partly removed upper Pleistocene gravels so in places left reached level $2 \mathrm{~m}$ above the bedrock. The first third of Holocene (time of all interpreted data) seems to be very stable from erosion/accumulation evolution point of view. More dynamic evolution started with accumulation of "higher flood-plain level" (from cca $214 \mathrm{~m}$ a. s. l. up to $221 \mathrm{~m}$ a. s. l.). Subsequent erosion formed relatively deep cut in the northwest part of the flood plain which was filled relatively quickly by sediments as consequence of deforestation connected with a colonization of upper parts of Bečva River drainage area. This is supported by finds of much younger subfossil trunks dated from 1 century $B C$ up to top of Middle-Age period in this accumulation (Vit et al. 2009). The surface of this accumulation is the so called "lower flood plain level" where periodicity of the inundation during floods is more regular then on the upper one.
\end{abstract}




\section{Úvod}

Údolní dna spolu s jejich vodními toky představují celek, který reaguje poměrně rychle na změny klimatu, tektonické procesy, zásahy člověka a s nimi svázané změny geomorfologických procesů. $\mathrm{V}$ zájmovém území se jim starší práce věnují spíše souborně, kdy jsou součástí systematického přehledu terasových stupňủ Bečvy (např. Tyráček 1957). Zájem o detailnější výzkum se projevil až s rozvojem datovacích technikv 80 . a 90. letech 20. století (archeologie, pedologie, palynologie, dendrochronologie a zejména radiouhlíkové datování), které postupně umožnily přesněji časově řadit události architekturní sedimentární stavby údolních výplní. Zajímavé výsledky tohoto výzkumu shrnul spolu se svojí představou vývoje sedimentace údolních den od pozdního glaciálu téměř do současnosti Czudek (2005).

Tato práce si vytkla za cíl podrobnější zpracování organickou hmotou bohatých poloh, které byly objeveny při terénním průzkumu na podzim roku 2016, kdy panovaly příznivé vodní stavy pro ohledání míst $\mathrm{v}$ těsné blízkosti hladiny vody. Důležitým aspektem je, že pozici těchto organikou bohatších poloh i subfosilního dřeva je možné popsat $v$ kontextu okolní sedimentární výplně a dosažené výsledky je tak možné zasadit do představy vývoje akumulace sedimentů údolního dna v okolí Oseku nad Bečvou. Kromě toho se je podařilo propojit is údaji zjištěnými v minulých letech (Vít et al. 2009; Kolář et al. 2014), kdy bylo zpracováno několik kmenů uložených ve výše položených štěrcích.

\section{Popis lokalit a situace odběrů vzorků}

Řeka Bečva vytváří v území mezi Hranicemi a Přerovem údolní nivu o šířce až $2,5 \mathrm{~km}$ (obr. 1 ). V tomto rozsahu může být zaplavována pouze za nejextrémnějších povodní, k nimž je možné zařadit povodeň z roku 1997. Tato vyvýšená část nivy bývá označována jako „vy̌̌ší nivní stupeň“, do jehož sedimentů je zahlouben erozní zářez, ve kterém probíhají hlavní procesy eroze a akumulace mladší části holocénu. Tato fluviální úroveň bývá označována jako „nižší nivní stupeň“ a zahrnuje vlastní aktivní koryto Bečvy, slepá ramena a akumulační tělesa mezi nimi, jejichž povrch je ve srovnání s vyšším nivním stupněm o 1-2 m níze. Taková stavba říční nivy byla pozorována i na jiných větších řekách např. na Labi (Rủžičková, Zeman 1994; Břízová 1999; Dreslerová et al. 2004). Podložím fluviálních sedimentů těchto erozních zářezů (údolního dna) jsou v této části údolí Bečvy především neogenní jílovité sedimenty karpatské předhlubně a spíše ojediněle i flyšové sedimenty kry Maleníku moravskoslezského paleozoika.

V okolí Oseku nad Bečvou jsou v prostoru nižžího nivního stupně odkryty na dvou místech $4-5 \mathrm{~m}$ vysoké profily fluviální výplní údolního dna řeky Bečvy. Prvním je štěrkovna, která se nachází asi $1 \mathrm{~km}$ j. od Oseku n. B., a druhým pak levý nárazový břeh Bečvy asi $1 \mathrm{~km}$ z. od Oldřichova. Na obou těchto místech se vyskytují subfosilní kmeny a jílovitá poloha bohatá na organickou hmotu.

\section{Lokalita Oldřichov}

Zde byl za povodně v roce $1997 \mathrm{v}$ korytě vytvořen asi $4 \mathrm{~m}$ vysoký výchoz fluviálních sedimentů o délce několika stovek metrů. Jako nejzajímavější se jeví ve směru

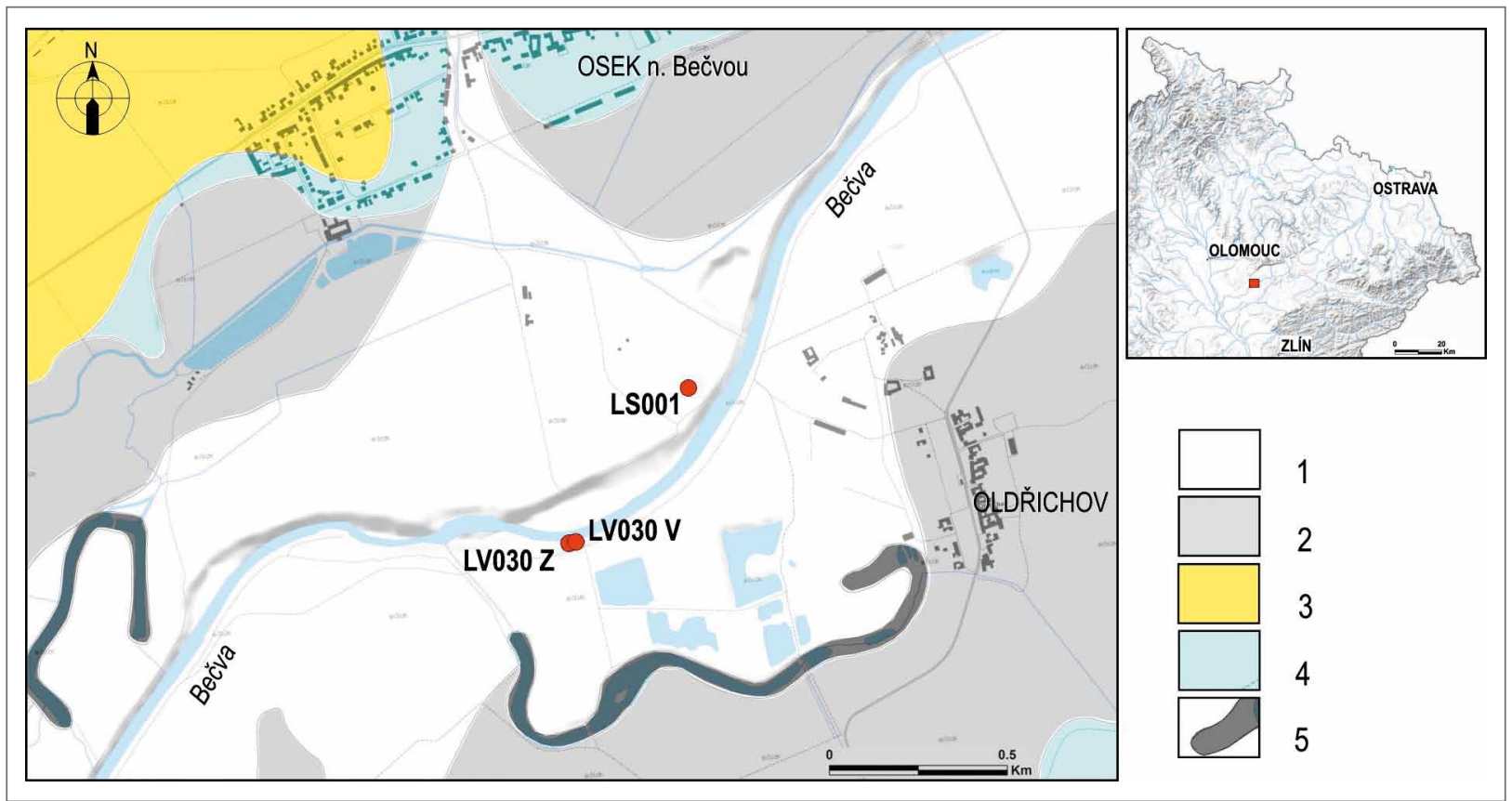

Obr. 1: Schematická geologická mapa nivy řeky Bečvy a přilehlého okolí u Oseku n. Bečvou a Oldřichova s pozicí zpracovávaných lokalit; 1 - sedimenty nižšího nivního stupně; 2 - sedimenty vyššího nivního stupně; 3 - spraše a sprašové hlíny; 4 - terasové sedimenty; 5 - organogenní sedimenty slepých ramen. Podkladová topografická vrstva $\odot$ ČÚZK.

Fig. 1: Schematic geological map of the Bečva River flood plain and surroundigs of Osek $n$. Bečvou and Oldřichov with position of the localities. 1- lower flood plain sediments; 2 - higher flood plain sediments; 3 - loess; 4 - terrace sediments; 5 - organogenic sediments of abandoned channels. 


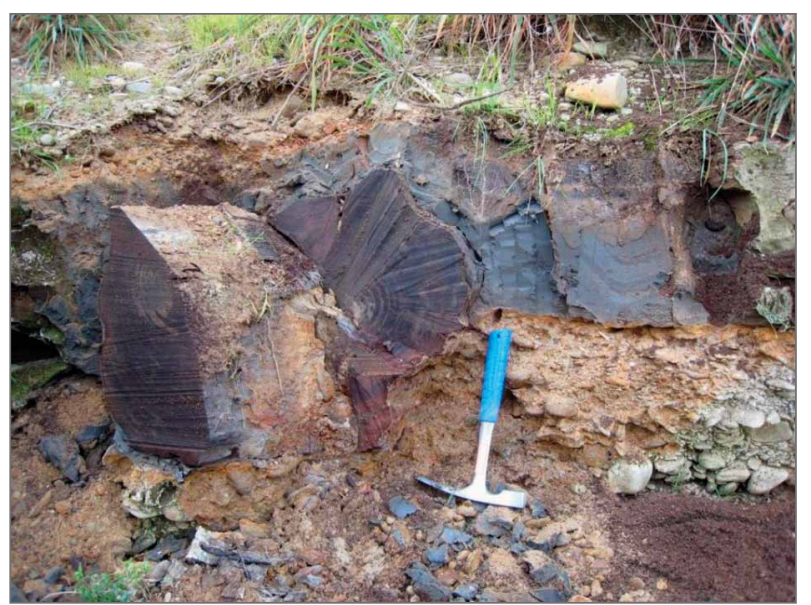

Obr. 2. Detail sedimentů zazemněného koryta se subfosilním kmenem vystupujícím z podložních štěrků (LV030 Z). Autor J. Vít.

Fig. 2: Oxbow sediments with subfossil trunk deposited in gravel on the base (LV030 Z). Author J. Vít

toku vzdálenější část nárazového břehu, kde se v dolní polovině profilu hojně vyskytují subfosilní kmeny, z nichž část byla v minulosti zpracována (Vít et al. 2009; Kolářr, Rybníček 2011).

V dokumentovaném místě (LV030 V a LV030 Z; GPS koorináty $\left.\mathrm{N} 49^{\circ} 29^{\prime} 50^{\prime \prime} \mathrm{E} 17^{\circ} 31^{\prime} 29^{\prime \prime}\right)$ vycházejí ve spodní části střredně zrnité štěrky tvořené polozaoblenými až zaoblenými valouny paleogenních pískovců, prachovců, ojediněle i drobnozrnných slepenců. V těchto štěrcích byl díky nízké hladině vody v řece objeven subfosilní kmen stromu, ze kterého byl odebrán vzorek na dendrologickou analýzu a dendrochronologické a radiometrické datování (obr. 2). Kmen zčásti zasahuje i do nadložních modravě šedých, místy narezavělých jílů s organickou příměsí. Jíly jsou mocné do $0,5 \mathrm{~m}$ a je možné je sledovat na delší vzdálenost. $\mathrm{Z}$ této polohy byly na dvou místech, vzdálených od sebe cca $20 \mathrm{~m}$, odebrány vzorky na analýzu palynomorf (LV030 V, LV030 Z). Rozsah této jílové vrstvy je patrně významnější, protože $\mathrm{z}$ báze nadložních štěrků pramení na několika místech voda, a vrstva tak představuje při nižší hladině vody bazální izolátor lokální zvodně. Tyto nadložní středně zrnité štěrky přecházejí výše do štěrků drobnozrnných, které při bázi s nadložními písky tvoří již jen čočkovité polohy. Písky jsou středně, místy hrubě zrnité, žlutavě šedé s výraznými rezavými polohami, lavicovitě uložené, jen při bázi převládá korytové zvrstvení. Směrem do nadloží písky přecházejí do písčitých hlín, jejichž povrch tvoří nižší nivní stupeň.

\section{Lokalita Osek nad Bečvou}

Druhým místem s nálezem polohy bohaté organickou hmotou je štěrkovna na opačném (pravém) břehu řeky situovaná $1 \mathrm{~km}$ j. od kostela Povýšení sv. kř́iže v Oseku nad Bečvou (LS001, N 49³0'07" E 17³1'48"). Štěrkovna má hloubku do $5 \mathrm{~m}$ a těžba probíhá až do úrovně těsně nad hladinu podzemní vody. I zde je př̀i bázi odkrýváno větší množství subfosilních kmenů, které představují komplikaci při těžbě (obr. 3). Stavba fluviální sedimentace je velmi podobná předchozí lokalitě v nárazovém

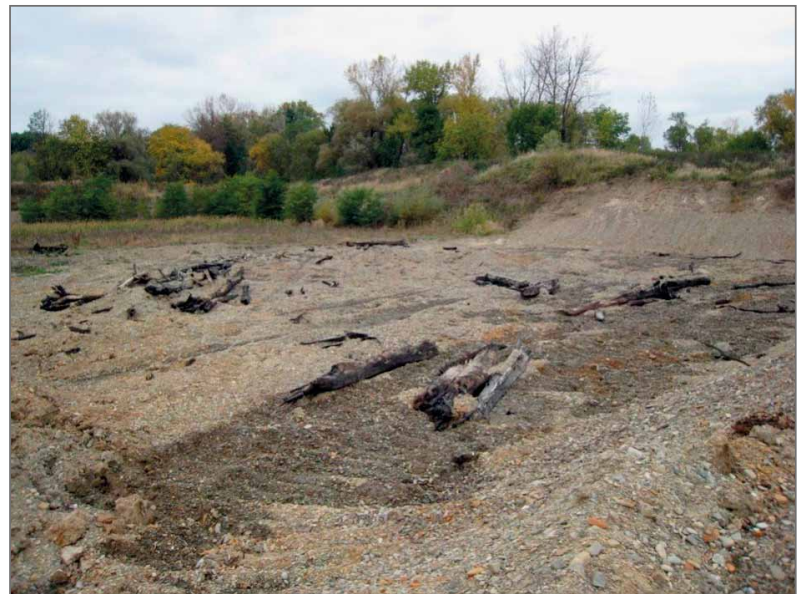

Obr. 3. Holocenní štěrky v pískovně u Oseku n. Bečvou s hojnými subfosilními kmeny (LS001). Autor J. Vít.

Fig. 3: Holocene gravel in the gravel pit by Osek n. Bečvou with subfossil trunks (LS001). Author J. Vít.

břehu řeky. Na bázi štěrkovny se nachází poloha šedého písčitého prachu s úlomky dřev a uhlíků, členěná tenkou vrstvou černohnědé organické hmoty. Vlastní bazální část nižšího nivního stupně je tvořena středně až hrubě zrnitým, šedým, místy rezavě zbarveným štěrkem tvořeným polozaoblenými až zaoblenými valouny pískovců různých zrnitostí až drobnozrnných slepenců, méně je zastoupen křemen a prachovce. Ve svrchních částech se štěrky střídají s polohami hrubě zrnitých písků, na které nasedá žlutavě hnědý středně, místy až hrubě zrnitý písek s drobnými zrny a valounky kolem $2 \mathrm{~mm}$ s čeřinami a korytovým zvrstvením. V nejsvrchnější části přibývá poloh jemnozrnných písků s postupným přechodem do asi $1 \mathrm{~m}$ mocné vrstvy povodňových hlín, kde je vrstevnatost nezřetelná a byla nejspíše setřena půdními procesy.

O stavbě sedimentární výplně pod úrovní hladiny podzemní vody na obou lokalitách je možné si udělat představu jen prostřednictvím vrtných prací, které byly prováděny $\mathrm{v}$ souvislosti s ověřováním zdrojů pro stavbu dálnic (Moravec et al. 1983; Svoboda 1987; Drobníčková, Pavlík 1995). V prostoru j. od Oseku n. Bečvou bylo zjištěno, že jde o sedimenty tvořené poměrně hrubými štěrky s valouny o průměru $4-10 \mathrm{~cm}$, ojediněle i $20 \mathrm{~cm}$, poprrípadě i hrubozrnnými písky, a jejich báze se nachází 1-3 m pod úrovní Bečvy. Tyto sedimenty tvoří bázi výplně údolí Bečvy a stratigraficky jsou řazeny do druhé poloviny svrchního pleistocénu, kdy byly akumulovány „divočícíc řekou.

\section{Metodika a výsledky Palynologický výzkum}

Sedimenty na pylovou analýzu byly odebrány ze západní (Z) i východní (V) části výchozu jílovité polohy na lokalitě Oldřichov (LV030), ale i z vrstvy černohnědé organické hmoty, která se nachází v rámci šedého písčitého prachu na lokalitě u Oseku n. Bečvou (LS001). Laboratorní zpracování probíhalo v laboratoři ČGS na Barrandově metodou používanou pro maceraci kvarterních organických sedimentů (HF, Erdtmanova 
acetolýza, palynomorfy uchovávány ve směsi glycerinu, destilované vody a etylalkoholu, Erdtman 1954).

Vzorek LV030 V obsahoval více anorganického materiálu a byl chudší na pylová zrna. Typ vegetace se výrazně lišil od ostatních vzorků (tab. 1). Nacházely se zde některé typy palynomorf typické spíše pro neogén, např. "tercierní typy čeledi Pinaceae (Teodoridis et al. 2017). Není však vyloučené, že se jedná pouze o redepozici ze starších sedimentů. Nedá se také vyloučit sedimentace spodního holocénu (nález chladnomilného vranečku Selaginella) s redeponovanými pylovými zrny. Vzorek

Tab. 1: Zastoupení pylových zrn.

Tab. 1: Pollen grain assemblage.

\begin{tabular}{|c|c|c|c|}
\hline vzorky/samples & LV030 V & LV030 Z & LS001 \\
\hline Sum AP & 10 & 103 & 116 \\
\hline Sum NAP & 8 & 12 & 68 \\
\hline $\mathrm{AP}+\mathrm{NAP}$ & 18 & 115 & 184 \\
\hline \multicolumn{4}{|l|}{ AP - dřeviny } \\
\hline Pinus & & 22 & 103 \\
\hline Pinus cembra typ & 2 & & 5 \\
\hline Betula & & 6 & 1 \\
\hline Juniperus & & & 1 \\
\hline Salix & & & 2 \\
\hline Corylus & & 4 & 1 \\
\hline Larix & 3 & & 1 \\
\hline Ulmus & 1 & 7 & \\
\hline Quercus & & 1 & \\
\hline Tilia sp. & & 4 & \\
\hline T. platyphyllos & 1 & 18 & \\
\hline T. cordata & & 6 & \\
\hline Alnus & & 3 & \\
\hline Picea & 2 & 29 & 1 \\
\hline Carpinus & & 2 & \\
\hline Sambucus nigra & & 1 & \\
\hline Populus & & & 1 \\
\hline Pinus typ „tercierni“ & 1 & & \\
\hline \multicolumn{4}{|l|}{ NAP - byliny } \\
\hline Poaceae & & & 5 \\
\hline Cyperaceae & & 1 & 47 \\
\hline Lemna & & & 6 \\
\hline Thalictrum & & 1 & \\
\hline Ranunculaceae & & 1 & \\
\hline Anemone typ & & & 1 \\
\hline Apiaceae & & & 1 \\
\hline Asteraceae Liguliflorae & & & 1 \\
\hline Saxifragaceae & & & 1 \\
\hline Verbascum & & 1 & \\
\hline Brassicaceae & & & 1 \\
\hline Chenopodiaceae & 2 & & \\
\hline Urtica & & & 2 \\
\hline Artemisia & 1 & 1 & 1 \\
\hline varia & 5 & 6 & 3 \\
\hline \multicolumn{4}{|l|}{ PTERIDOPHYTA } \\
\hline Selaginella selaginoides & 2 & & \\
\hline Polypodiaceae & 1 & 1 & 1 \\
\hline Dinoflagellata & & 1 & \\
\hline \multicolumn{4}{|l|}{ RHIZOPODA } \\
\hline Hyalosphaenia subflava & & & 1 \\
\hline Arcella & & & 1 \\
\hline
\end{tabular}

obsahoval velmi malé množství palynomorf, kdy se dá určit pouze, že se jedná o chladnomilnou stepní vegetaci (napřr. Artemisia, Chenopodiaceae) na našem území pravděpodobně z počátku holocénu.

Vzorek LV030 Z obsahoval více organického materiálu a byl bohatší na sporomorfy. Poměr dřevinné složky AP a bylinné složky NAP byl ve prospěch dřevin (86: 14), což dokazuje zalesněnost území. Složení pylového spektra ukazuje na holocenní stáří sedimentu, možná jde o klimatické optimum (atlantik), to je z jednoho vzorku těžké blíže určit. Z dřevin převažuje borovice (Pinus), smrk (Picea) a lípa (Tilia sp., T. platyphyllos, T. cordata). Bylinné spektrum je velice chudé. Také je zde doložena redepozice v podobě Dinoflagellata (obr. 4).

Vzorek LS001 obsahoval také dostatečné množství palynomorf pro procentuální vyhodnocování. Dřevinná složka pylového spektra jako borovice (Pinus, P. cembra typ), vrba (Salix), jalovec (Juniperus), líska (Corylus) spíše indikují počátek holocénu. V bylinné složce převažují typy čeledi Cyperaceae charakterizující mokřadní bažinnou vegetaci místy s vodní hladinou (Lemna). Bylinné spektrum je celkově pestré (tab. 1).

Dendrochronologický výzkum a radiometrické datování

K lepšímu pochopení stratigrafických poměrů ve zkoumané oblasti přispěl především nález subfosilního kmene, který je uložen v přímém podloží jílové vrstvy s organickou hmotou na lokalitě Oldřichov (LV030 Z).

Pomocí motorové pily byl z kmene odebrán vzorek v podobě příčného řezu. Po úpravě povrchu byla nejprve provedena anatomická identifikace druhu dřeva na makroskopické úrovni na základě práce Schweingrubera (1990). Následně byl vzorek změřen ve dvou různých směrech na měřicím stole VIAS TimeTable (SCIEM). Letokruhové křivky byly měřeny (s přesností $0,01 \mathrm{~mm}$ ) a synchronizovány v programu PAST4 (SCIEM). Podobnost mezi jednotlivými křivkami byla hodnocena pomocí t-testů (Baillie, Pilcher 1973; Hollstein 1980), koeficientu souběžnosti (Eckstein, Bauch 1969) a vizuálního porovnání, které je pro účely datování klíčové (Rybníček et al. 2010). Z jednotlivých letokruhových křivek byla následně vytvořena průměrná letokruhová křivka reprezentující daný vzorek, která byla porovnána s dostupnými standardními chronologiemi. Zkoumaný vzorek byl anatomicky identifikovaný jako jasan (Fraxinus sp., obr. 5B). $\mathrm{V}$ podobě subfosilních kmenů se jedná o výjimečný nález, protože převážně jsou u těchto nálezů zastoupeny duby (Kolář, Rybníček 2011). Protože pro jasan v České republice neexistuje standardní chronologie, křivka byla porovnána s dubovými standardními chronologiemi. Statisticky významná korelace mezi oběma druhy byla již dříve prokázána (např. Čufar et al. 2008). Avšak vzorek nebylo možné spolehlivě dendrochronologicky datovat podle nejnovější verze české dubové standardní chronologie (Prokop et al. 2017), proto byly vybrány dva vzorky $\mathrm{z}$ kmene (jeden ze středové části a druhý $\mathrm{z}$ povrchové části kmene), které byly odeslány k radiouhlíkovému datování na Ústav jaderné fyziky AV ČR v Praze. Výsledky byly 

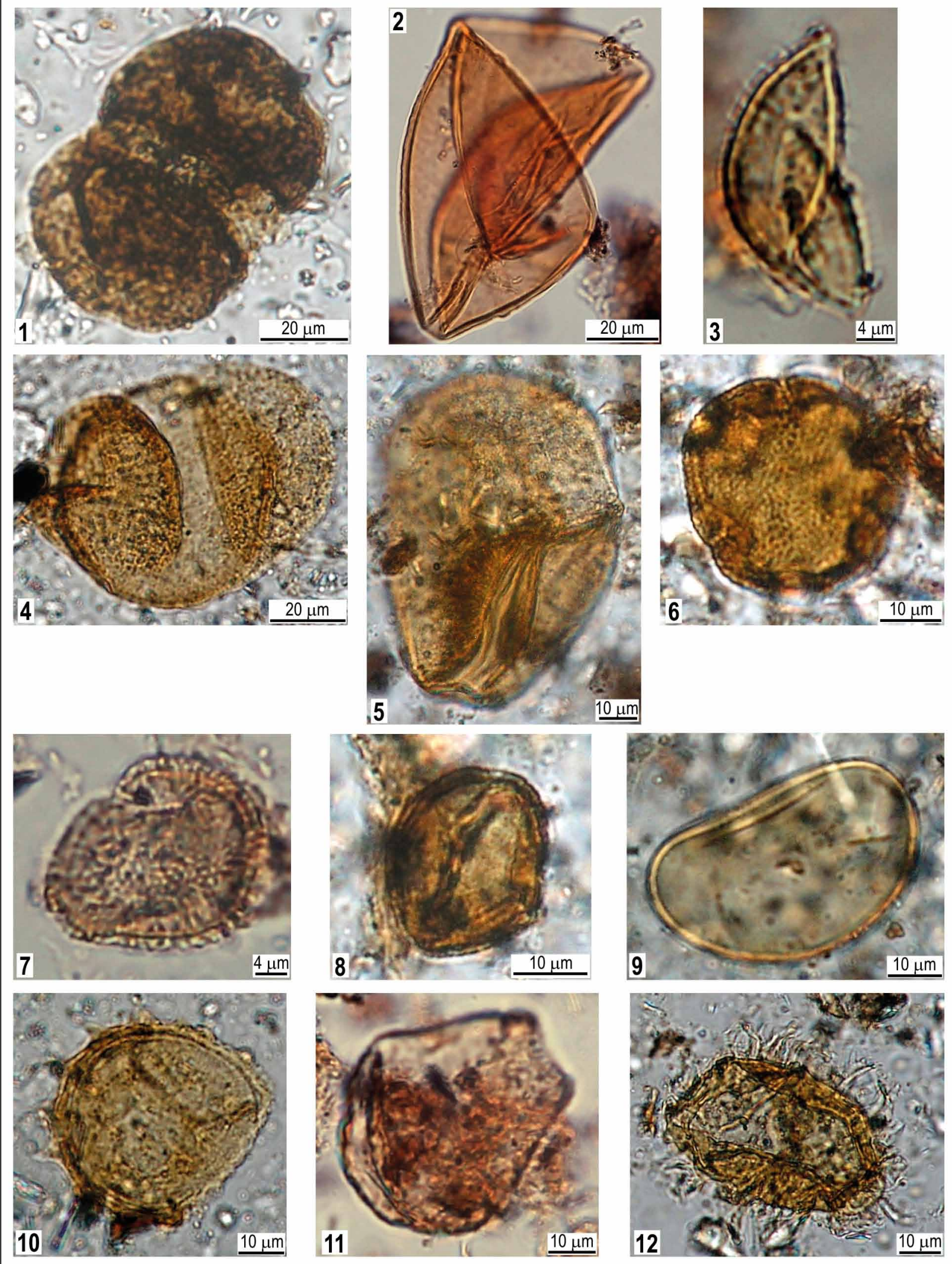

Obr. 4: Palynomorfy z lokalit Osek n. Bečvou a Oldřichov. AP: 1 - Pinaceae typ „tercierní“, LV030 V; 2 - Larix, LS001; 3 - Juniperus, LS001; 4 - Pinus cembra typ, LV030 V; 5 - Picea, LV030 Z; 6 - Tilia platyphyllos, LV030 Z. NAP: 7 - Brassicaceae, LS001; 8 - Verbascum, LV030 Z; Spory: 9 - Polypodiaceae, LV030 V. 10 - Selaginella, LV030 V; 11 - Hyalosphaenia subflava, LS001; 12 - Dinoflagellata, LV030 Z. Autor E. Břízová.

Fig. 4: Pollen grains from the localities Osek n. Bečvou a Oldřichov. AP. 1 - Pinaceae type „tertiary“, LV030 V; 2 - Larix, LS001; 3 - Juniperus, LS001; 4 - Pinus cembra type, LV030 V; 5 - Picea, LV030 Z; 6 - Tilia platyphyllos, LV030 Z. NAP: 7 - Brassicaceae, LS001; 8 - Verbascum, LV030 Z. Pollen: 9 - Polypodiaceae, LV030 V; 10 - Selaginella, LV030 V; 11 - Hyalosphaenia subflava, LS001; 12 - Dinoflagellata, LV030 Z. Author E. Břízová. 


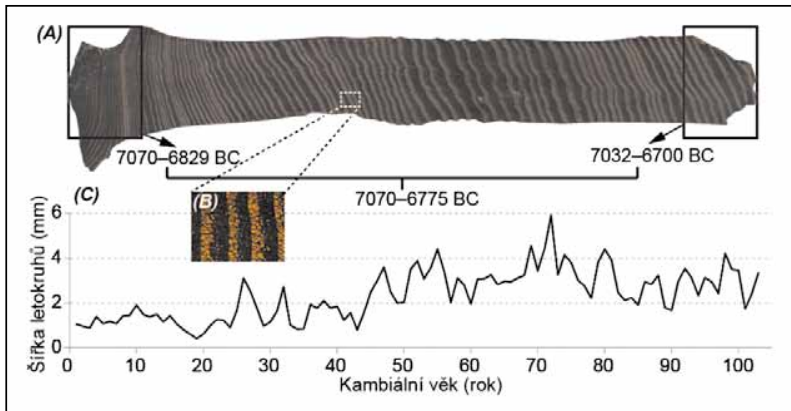

Obr. 5: A - Radiouhlíkové datování odebraného vzorku kmene s použitím metody wiggle matching; B - identifikace druhu dřeva na mikroskopické úrovni jako jasan (Fraxinus sp.); $\mathrm{C}$ - naměřená letokruhová křivka.

Fig. 5: A - Radiocarbon dating of the sampled trunk using wiggle matching method; $\mathrm{B}$ - microscopic identification of the wood species as ash (Fraxinus sp.); $\mathrm{C}$ - measured tree-ring curve.

získány na přístroji MICADAS a kalibrovány programem OxCal v4.2.4 (kalibrační křivka IntCal13).

Více jak stoletý jasan (Fraxinus spp., obr. 5B, 5C) byl na základě radiouhlíkového datování dvou vzorků od sebe vzdálených více jak 50 letokruhů a použitím metody wiggle matching datován do období 7 070-6 775 BC (obr. 5A).

\section{Diskuze a závěr}

V prostoru nivy řeky Bečvy jz. od Lipníku n. Bečvou byly na 2 lokalitách (štěrkovna Osek n. B. a nárazový břeh Bečvy u Oldřichova) získány nové poznatky o stavbě výplně údolního dna podpořené daty radiometrického, dendrologického a palynologického výzkumu. Interpretace těchto dat umožnuje vytvořit celkový nástin akumulace sedimentů údolního dna Bečvy v tomto zájmovém prostoru.

Všechna nová data pocházejí z míst v těsné blízkosti hladiny řeky Bečvy a návazně i hladiny podzemí vody (cca nadmořská výška $214 \mathrm{~m}$ ), což je podle vrtných prací 1-2 m nad bází fluviální výplně údolního dna (např. Moravec et al. 1983).

Zásadní pro představu o vývoji akumulace sedimentů je jejich stáří. Za nejstarší, alespoň nepřímými daty dokladovaný, sediment můžeme považovat jílovitou polohu ve štěrkovně u Oseku n. B. (LS001), jehož stáří bylo na základě palynologické analýzy interpretováno jako počátek holocénu (preboreál?). Z druhé lokality (Oldřichov, LV030 Z a LV030 V) byly palynologicky zpracovány 2 vzorky, ale pouze jeden $\mathrm{z}$ nich přinesl relevantní množství určitelného materiálu, aby jeho stáří mohlo být interpretováno. Tento palynomorfy bohatší vzorek byl interpretován jako klimatické optimum (atlantik). Tato interpretace je v dobrém souladu s údaji, které poskytlo radiouhlíkové datování kmene jasanu, který je součástí vrstvy štěrků v přímém podloží a který zasahuje i do jílovité polohy s údaji palynologickými. Radiometricky byl kmen datován na 7 070-6 775 BC (kolem 7000 let před Kristem), což odpovídá boreálu. Rovněž izopolové mapy (Rybníčková 1985) naznačují, že právě v tomto období mohlo docházet $\mathrm{k}$ rozšiřování jasanu na území
ČR, protože do této doby bylo jeho zastoupení velmi malé v porovnání s ostatními dřevinami napřr. rody Pinus nebo Betula. Všechny údaje tedy časově spadají do starší poloviny holocénu.

Z hlediska vlastního vývoje sedimentace lze předpokládat, že koncem pleistocénu došlo k závěrečnému prohloubení koryta Bečvy. Z následné akumulace (většinou štěrků) je do současnosti v tomto prostoru zachováno jen 1-2 m. Období spodního a zčásti i středního holocénu lze ze sedimentace interpretovat jako poměrně klidné, kdy řeka vytvářela meandrující tok s množstvím odškrcených ramen. Tento erozně-akumulační cyklus má při porovnání výšek lokalit minimální výškový rozsah, který se pohybuje kolem $1 \mathrm{~m}$. Následující období bylo již mnohem dynamičtější, protože muselo dojít $\mathrm{k}$ akumulaci dalších sedimentů vyššího nivního stupně o mocnosti téměř $7 \mathrm{~m}$ a následné erozi, která se již soustředila do prostoru dnešního nižšího nivního stupně. Tato dosáhla až do blízkého nadloží radiouhlíkově datovaného jasanu, nebot' nadložní štěrky, které již představují akumulaci nižšího nivního stupně, obsahují velké množství kmenů dubů, které byly v minulosti rovněž radiometricky datovány (Vít et al. 2009, obr. 6). Zde uložené nejstarší dubové kmeny pocházejí z konce subboreálu (945-405 BC), ale nejmladší dubové kmeny pocházejí z vrcholného středověku, což znamená, že hluboké erozní koryto ve vyšším nivním stupni bylo vyplněno až v období posledních 500 let jako odezva na středověkou kolonizaci horního toku Bečvy, která byla spojená s odlesněním a větším transportem splavenin.

Nálezy organické hmoty (především pylová zrna, drobná dřevní hmota, subfosilní kmeny), se kterými je možné se občas setkat, představují při všech problémech, způsobených jejich možnou redepozicí (viz např. Kalicki, Krapiec 1995), cenné opěrné body pro dešifrování vývoje akumulací údolních den. Každý z takových nálezů, který je možné zasadit do okolního sedimentárního záznamu, je cenným př́íspěvkem $\mathrm{k}$ řešení dynamického vývoje

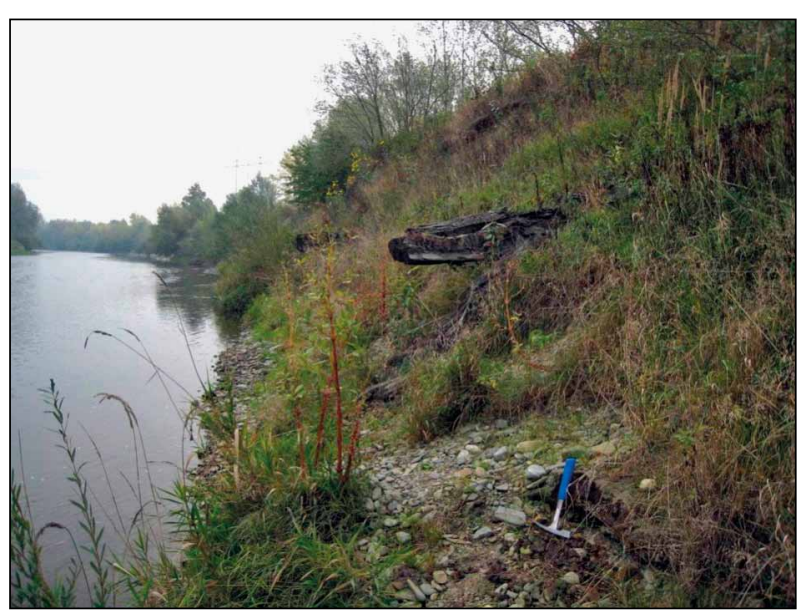

Obr 6: Levý břeh Bečvy u Oldřichova s mladšími subfosilními kmeny. Kladivo lokalizuje polohu palynologicky zkoumaného jílu (vzorek LV030 V). Autor J. Vít.

Fig. 6: Left bank of the River Bečva by Oldřichov with younger subfossil trunks. The hammer is localising the position of analysed clay (sample LV030 V). Author J. Vít. 
údolního systému a př́íspěvkem k odlišení lokálních a globálních změn.

\begin{abstract}
Poděkování
Tento príspèvek vznikl díky podpoře projektu GA18-11004S, Extension of the Czech Millennia-long Oak Tree-ring width Chronology a projektu 321070, Registr svahových nestabilit (části geologická rizika - povodně). V neposlední řadě bychom chtěli poděkovat i oběma recenzentưm za cenné pripomínky.
\end{abstract}

\section{Literatura}

Baillie, M. G. L., Pilcher, J. R. (1973). A simple cossdating program for tree-ring research. - Tree-Ring Bulletin 33, 7-14.

Bř́zová, E. (1999). Late Glacial and Holocene development of the vegetation in the Labe (Elbe) River flood-plain (Central Bohemia, Czech Republic). - Acta Paleobot. Suppl. 2 - Proceedings 5th EPPC, 549-554. Kraków.

Czudek, T. (2005). Vývoj reliéfu krajiny České republiky v kvartéru. - 238 s., Moravské zemské muzeum. Brno. ISBN 8070282703

Čufar, K., Luis, M. D., Zupančič, M., Eckstein, D. (2008). 548-year tree-ring chronology of oak (Quercus spp.) for southeast Slovenia and its significance as a dating tool and climate archive. - Tree-Ring Research 64 (1), 3-15. https://doi.org/10.3959/2007-12.1

Dreslerová, D., Břízová, E., Růžičková, E., Zeman, A. (2004). Holocene environmental processes and alluvial archaeology in the middle Labe (Elbe) valley. - In: Gojda, M. (ed.): Ancient landscape, settlement dynamics and non-destructive archaeology. Academia, Praha, 121-171.

Drobníčková, H., Pavlík, J. (1995). Závěrečná zpráva o průzkumu nalezišt násypových materiálů pro výstavbu D 35 a obchvatu Lipníka nad Bečvou. - MS, Geotest, a.s., Brno.

Eckstein, D., Bauch, J. (1969). Beitrag zur Rationalisierung eines dendrochronologischen Verfahrens und zur Analyse seiner Aussagesicherheit. - Forstwissenschaftliches Centralblatt 88, 230-250. https://doi.org/10.1007/BF02741777

Erdtman, G. (1954). An introduction to pollen analysis. - Waltham (USA).

Hollstein, E. (1980). Mitteleuropäische Eichenchronologie. Trierer dendrochronologische Forschungen zur Archäologie und Kunstgeschichte. - Trierer Grabungen und Forschungen. Mainz am Rhein, 274 pp.

Kalicki, T., Krapiec, M. (1995). Problems of dating alluvium using buried subfossil tree trunks: lessons from the black oaks of the Vistula Valley, Central Europe. - The Holocene, 5, 243-50.

Kolář, T., Rybníček, M. (2011). Dendochronological and radiocarbon dating of subfossil wood from the Morava River basin. Geochronometria 38(2), 155-161. https://doi.org/10.2478/s13386-011-0021-x

Kolář, T., Rybníček, M., Stř̌elcová, M., Hedvábný, J., Vít, J. (2014). The changes in chemical composition and properties of subfossil oak deposited in Holocene sediments. - Wood Research, Vol. 59, No. 1, 149-165. Slovak Forest Products Research Institute. Bratislava.

Moravec, Č., Peichel, S., Ševčík, J., Špíchalová, D., Staňková, L. (1983). Povodí Bečvy. Úsek Hranice - Přerov. Souhrnná závěrečná zpráva. Surovina štěrkopísek. Etapa vyhledávací. - MS, Unigeo, závod Ostrava (ČGS Geofond, P054388).

Prokop, O., Kolář, T., Kyncl. T., Rybníček, M. (2017). Updating of the Czech millennia-long oak tree-ring width chronology. Tree-ring Research 73(1): 47-52. http://dx.doi.org/10.3959/1536-1098-73.1.47

Růžičková, E., Zeman, A. (1994). Paleogeographic development of the Labe river flood plain during the Holocene. - In: Rủžičková E. et Zeman A. (eds): Holocene flood plain of the Labe river. Contemporary state of research in the Czech Republic. 104-112. Prague.

Rybníček, M., Koňas, P., Kolář, T. (2010). The benefits of tree-ring curves detrending for dating archaeological wood. - Geochronometria, 35, 85-90.

Rybníčková, E. (1985): Dřeviny a vegetace Československa v nejmladším kvartéru. - MS, disertační práce. Institut systematické a ekologické biologie, Brno.

Schweingruber, F. H. (1990). Anatomy of European woods. An atlas for the identification of European trees, shrubs and dwarf shrubs. - 800 s. Paul Haupt Publisher, Berne, Switzerland and Stuttgart, Germany.

Svoboda, R. (1987). Zpráva o výsledku předběžného průzkumu nalezišt násypového a konstrukčního materiálu pro stavbu dálnice D35 na lokalitách Rokytnice, Týn n. Bečvou, Osek n. Bečvou, Rybáře, Oldřichov. - MS, Geotest, Brno.

Tyráček J. (1957). Jihozápadní část Moravské brány mezi Lýskami a Lipníkem nad Bečvou na topografických sekcích 4259/1 a 4159/3. - Antropozoikum, VI, 166-171.

Teodoridis, V., Bruch, A. A., Vassio, E., Martinetto, E., Kvaček, Z., Stuchlik, L. (2017). Plio-Pleistocene floras of the Vildštejn Formation in the Cheb Basin, Czech Republic. - A floristic and palaeoenvironmental review. - Palaeogeography, Palaeoclimatology, Palaeoecology 467, 166-190. http://dx.doi.org/10.1016/j.palaeo.2015.09.0380031-0182

Vít, J., Kolář, T., Rybníček, M. (2009). Předběžné výsledky studia vztahu subfosilních kmenů a fluviálních sedimentů na lokalitách Osek nad Bečvou a Tovačov-Annín. - Geologické výzkumy na Moravě a ve Slezsku v r. 2008, 53-55. Brno. 